Original Article

\title{
Copaiba oil and Neem extract can be a potential alternative for the behavioral control of Sitophilus zeamais
}

\author{
Óleo de copaíba e o extrato de Neem podem ser uma alternativa potencial para o \\ controle comportamental do Sitophilus zeamais
}

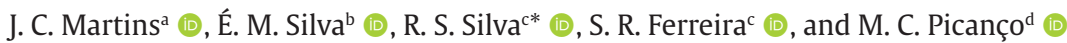 \\ anstituto Federal de Educação, Ciência e Tecnologia Baiano - IF Baiano, Teixeira de Freitas, BA, Brasil \\ bUniversidade Federal de Viçosa - UFV, Instituto de Ciências Agrárias, Rio Paranaíba, MG, Brasil \\ cUniversidade Federal dos Vales do Jequitinhonha e Mucuri - UFVJM, Departamento de Agronomia, Diamantina, MG, Brasil \\ dUniversidade Federal de Viçosa - UFV, Departamento de Entomologia, Viçosa, MG, Brasil
}

\begin{abstract}
Insects' ethology is an important factor when it is desired to carry out pest management. This knowledge makes it possible to manipulate behavioral activities, repel, or attract insects according to needs and interests. The maize weevil Sitophilus zeamais (Mots., 1855) (Coleoptera: Curculionidae), one of the main stored grain pests, has been the target of studies of behavioral changes studies through natural substances due to its resistance to different insecticidal classes. Thus, this study aimed to evaluate the effect of sublethal concentrations of neem extract and copaiba oil on the locomotor behavior of S. zeamais. The behavioral characteristic considered were walking activity, the frequency of contact of insects with the treated grain mass, and the time spent for this behavior. The walking activity of the S. zeamais increased with exposure to Neem extract and Copaiba oil. In general, the Neem extract and Copaiba oil-induced more contact with grain mass than the control, suggesting an attractive effect on the insect, however more significant for the Neem oil. The insect's behavior was altered, presenting a specific path due to Copaiba oil and Neem extract stimuli. These results indicate that Copaiba oil and Neem extract can be a potential alternative for controlling $S$. zeamais on stored products since changes in this pests' behavior can reduce qualitative and quantitative grain damage. Thus, the development of products based on Copaiba oil and Neem extract may be helpful for storage pest management.
\end{abstract}

Keywords: botanical insecticide, behavior, alternative control, pest management.

\begin{abstract}
Resumo
A etologia dos insetos é um fator importante quando se deseja relizar manejo de pragas. Através deste conhecimento, é possível manipular atividades comportamentais, repelir, ou atrair os insetos de acordo com as necessidades e interesses. O gorgulho do milho Sitophilus zeamais (Mots., 1855) (Coleoptera: Curculionidae), uma das principais pragas de grãos armazenados tem sido alvo de estudos de alterações comportamentais através de substâncias naturais devido à sua resistência a diferentes classes de insecticidas. Assim, este estudo teve como objetivo avaliar o efeito de concentrações subletais de extrato de neem e do óleo de copaíba sobre o comportamento de movimentação de S. zeamais. As características comportamentais consideradas foram: a atividade de caminhamento, a frequência do contato dos insetos com a massa de grãos tratada, e o tempo gasto para realização destes comportamentos. A atividade de caminhamento do $S$. zeamais aumentou quando os insetos foram expostos ao extrato de Neem e ao óleo de copaíba. Em geral, o extrato de Neem e o óleo de Copaíba induziram mais contato com a massa de grãos do que o controle, sugerindo um efeito atrativo sobre o inseto, contudo este efeito foi mais significativo para o óleo de Neem. O comportamento do inseto foi alterado, apresentando um caminhamento específico devido aos estímulos do óleo de copaíba e do extrato de Neem. Estes resultados indicam que o óleo de copaíba e o extrato de Neem podem ser alternativas potenciais para o controle do $S$. zeamais em produtos armazenados, uma vez que alterações no comportamento desta praga podem reduzir os danos qualitativos e quantitativos nos grãos. Assim, o desenvolvimento de produtos baseados no óleo de copaíba e no extrato de Neem pode ser útil para o manejo de pragas de armazenamento.
\end{abstract}

Palavras-chave: inseticida botânico, comportamento, controle alternativo, manejo de pragas.

*e-mail: ricardo.ufvjm@gmail.com

Receive: July 26, 2021 - Accepted: January 19, 2022

This is an Open Access article distributed under the terms of the Creative Commons Attribution License, which permits unrestricted use, distribution, and reproduction in any medium, provided the original work is properly cited. 


\section{Introduction}

The success of insects stems from their ability to interpret stimuli in their surroundings (Gullan and Cranston, 2017). Through this knowledge, it is possible to strategize to manipulate behavioral activities, repellency, or attract insects. However, this sensitive capacity can also be linked to their failure in pest management since artificial stimuli can modify their behaviors aiming at agronomic interests. In this context, sublethal doses have satisfactory effects; Lee (2000) states that most insect pests show reduced fertility and longevity and interruption in activity-centered behavior when in contact with sublethal insecticide doses. Therefore, studies are needed on the behavioral reactions of insects to sublethal doses of insecticides since the effectiveness of pesticides may be reduced by the pesticide avoidance behavior of insects.

The maize weevil, Sitophilus zeamais (Mots., 1855) (Coleoptera: Curculionidae), stands out as one of the most important pests of stored grains in Brazil, mainly maize, rice, and wheat grains (Guedes, 1991). S. zeamais as a pest is because of its high biotic potential, high capacity to penetrate the grain mass, and resistance to different synthetic insecticides (Guedes et al., 1995). However, its infestation process can begin in the field, before the grain is harvested, and then facilitate cross-infestation in storage units (Ajibola Taylor, 1971; Likhayo and Hodges, 2000).

Plants with insecticidal actions have been used as an alternative method of controlling $S$. zeamais in products stored through powder formulations, oils, and extracts. Nwachukwu and Asawalam (2014) highlighted the potential of garlic juice in controlling S. zeamais. The Ruta graveolens leaves also proved to manage this species (Perera et al., 2017).

Azadirachta indica A. Juss (Meliaceae), popularly known as Neem, has also stood out to control S. zeamais and other insect species. Rodríguez (1999) reports the use of leaves, seeds, and seed oil of Neem A. indica for the control of Rhyzopertha dominica (Fabr., 1792), S. oryzae (L., 1763), Tribolium castaneum (Herbst., 1797), T. Confusum (Jacquelin du Val, 1868), Callosobruchus chinensis (L. 1758), C. maculatus (Fabr., 1775) and Oryzaephilus surinamensis (L., 1758), using powder at $1 \%$ concentration, and oil, between 0.2 and $0.5 \%$. Diseases-carrying insects are also targets for plant extracts (Mituiassu et al., 2022; Cansian et al., 2023). Nwachukwu and Asawalam (2014) obtained significant results in the mortality rate of $S$. zeamais and the reduction of progeny and population, and an increase in the germination rate of corn grains treated using neem seed oil and commercial product based on A. indica (NeemAzal).

Copaifera langsdorffii Desf. (Fabaceae) is toxic against Aedes aegypti (L., 1762) (Diptera: Culicidae) and has an efficiency of $100 \%$ after two days of exposure (Mendonça et al., 2005). In the management of agricultural pests, the aqueous extract of the leaves and bark of C. langsdorffii harmed the larvae of Spodoptera frugiperda (J. E. Smith, 1797), causing a reduced food intake, decreased larval and pupal weight, increased larval stage, and reduced fertility (Sâmia et al., 2016).

Natural products in pest control have advantages such as low persistence in the environment, rapid pest control, and low toxicity to natural enemies (Cloyd, 2012). However, it should be noted that biological activity may not be associated with its mortality. Sublethal effects can also be significant as lethal effects. The impact of natural products on insects is variable and can be toxic, repellent, attractiveness, cause sterility, modify behavior, development, or reduce food (Arnason et al., 1988; Formentini et al., 2016; Santana et al., 2021; Ilahi et al., 2021). Thus, this study's objective was to verify the effect of the sublethal dose on the behavior of S. zeamais for the extract of $A$. indica and oil of Copaifera sp.

\section{Material and Methods}

\subsection{Study location and insect collection}

The behavioral bioassays were carried out at the Integrated Pest Management Laboratory of the Universidade Federal de Viçosa (UFV), Minas Gerais, Brazil. The insects came from this laboratory's rearing under the following conditions: Glass containers ( $1.5 \mathrm{~L}$ ) containing insecticidefree whole maize grains ( $13 \%$ moisture content) as a food source and controlled relative humidity (75 $\pm 5 \%$ ), temperature (25 $\pm 5^{\circ} \mathrm{C}$ ), and 12-hour photophase. The insects were replicated and maintained in large numbers ( $<500$ individuals per container). The glass jars were perforated in the lid and sealed with an organza cloth. The grains used to raise the insects were washed and kept in a freezer $\left(-10^{\circ} \mathrm{C}\right)$ for thirty days to eliminate eventual organisms and avoid reinfestation. The grains in the jars were renewed whenever necessary, usually when insect infestation was very high, and the grains already deteriorated.

\subsection{Obtaining extracts}

Fresh fruits of $A$. indica (approximately $3.2 \mathrm{~kg}$ ) were collected at the field in Viçosa, Minas Gerais, Brazil, to extract. The raw material was chopped into 1 to $2 \mathrm{~cm}$ fragments and packed in Erlenmeyer for extraction using hexane as solvent according to the methodology used by (Moreira et al., 2007). Sufficient hexane was added for the complete immersion of plant material. The solvent was changed into intervals of two days, during 20 days. The extraction was concluded when the solvent stayed colorless, indicating that the transfer of the plant components into the solvent was no longer occurring. The extract obtained was concentrated on a rotary evaporator at low pressure $(0.08 \mathrm{MPa})$ and temperature $\left(<50^{\circ} \mathrm{C}\right)$. The extraction was concluded when the solvent stayed colorless. After the extraction and concentration, the resulting extract was stored under ultra-low temperature refrigeration for later use in biological tests.

Copaíba oil was obtained on the local market in Rio Branco, Acre, Brazil.

\subsection{Behavioral bioassays}

The bioassays were carried out in Petri dishes $(15 \mathrm{~cm}$ in diameter), the bottom of which was covered with paper to facilitate the insect's movement and allow it to 
deviate if necessary. The Petri dishes' edges were covered with talc to prevent the insect from leaving and restrict its movement only at the bottom of the dish. The preassessment insects were agitated when removed from the rearing containers and transferred to the experimental Petri dishes. This observation verified in the pre-experiment was important because we could identify the need for a period of adaptation of the insects outside the rearing pot and the experimental arena and, therefore, avoid the behavior exhibited by the insects that were different from the behavior stimulated by the treatments. Thus, insects used in the bioassays were separated from the rearing at the end of the previous day ( $6 \mathrm{pm}$ ) for pre-adaptation to the experimental conditions and therefore only used the next day. About 10 grains of corn were used in each repetition, the same used in the rearing, treated, and positioned in the Petri dish's central region. The bioassays were established following a completely randomized design with three treatments and ten replicates. The extract and oil were pasty to measure in $\mathrm{mL}$, so the mass was weighed and solubilized in hexane. Thus, the treatments were pure hexane (control), hexane plus Copaifera sp., and hexane plus extract Azadirachta indica, using $3.33 \mathrm{mg}$ of extract or oil / 10 grains / $2 \mathrm{~mL}$ of hexane. Our concentration approximates the concentration of $0.15 \mathrm{~mL} / 50 \mathrm{~g}$ of corn (equivalent to $3 \mathrm{~mL} / \mathrm{kg}$ of grain) (Tofel et al., 2017). The tests were carried out under constant light at room temperature under laboratory conditions. For each treatment, two insects/repetitions were used.

In the behavioral evaluation, the insects were observed for about 30 minutes for each repetition, where the recorded was done by registering the behavior, how many times they were performed, and the time spent on them in seconds. Specifically, the latency period (i.e., the time it took for the insect to reach the grain mass in the center of the Petri dish for the first time), the number of visits to the grain mass (the number of times the insect reached, left, and returned to the grain mass), and the walking frequency (how many times the insect was left walking around the Petri dish without being in contact with the treated grains during the 30 -minute monitoring period) were determined.

One of the insects was marked with green water-based paint so that there was a distinction between them. The walking behavior was only registered when the insect left the edge of the Petri dish. Through behavioral observations, an ethogram was constructed based on the treatment that most differed from the control. The data obtained were transformed according to equation $(\sqrt{x+0.5})$, to homogenize the variances. After being changed, the data were subjected to analysis of variance and the means separated by the Tukey test at $5 \%$ probability, using the SAEG-5.0 program (Gomes, 1992).

\section{Results}

In the evaluation of the sublethal effects of Neem extract and Copaíba oil to S. zeamais, significant differences were detected in the insect's behavior as a function of the latency period $\left(\mathrm{F}_{2 ; 38}=3.59 ; P<0.05\right)$, number of visits the grain mass $\left(\mathrm{F}_{2 ; 57}=3.64 ; P<0.05\right)$ and the walking frequency $\left(F_{2 ; 57}=6.91 ; P<0.05\right)$. There was no significant difference in permanence time in the grain mass $\left(\mathrm{F}_{2 ; 57}=1.40 ; P>0.200\right)$.

The neem extract showed the shortest latency period concerning the control, although it was not statistically different from Copaíba oil. Control and Copaíba oil were statistically similar (Figure 1 ). The longest average time for S. zeamais to first contact grains was recorded for the control. Not all insects had contact with the grain mass treated as the extract of $A$. indica.

Regarding the number of times that the insect reached the grain mass, those treated with the Neem extract were the ones that most often had S. zeamais contact, although it is not, however, statistically different from Copaíba oil. Visits to grains treated with Copaíba oil did not differ from the control (Figure 2).

S. zeamais in the treatments with the extract of Neem and the oil of Copaíba was superior to the control for walk frequency (Figure 3). In evaluating the residence time in the grain mass in decreasing order, the longest time was for treatment with neem extract and followed by Copaíba oil. However, there was no statistical difference between treatments and control (Figure 4).

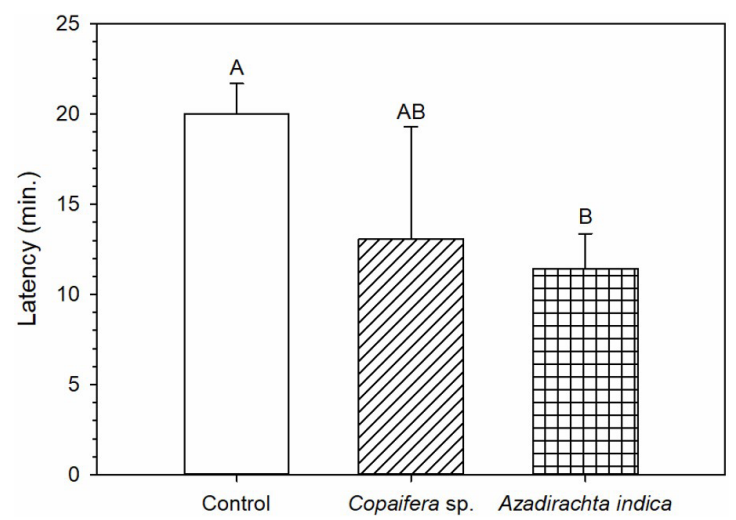

Figure 1. Time (mean \pm standard error) in minutes spent by the insect to reach the grain mass for the first time in the different treatments. The bars followed by the same capital letter do not differ by Tukey's test $(\mathrm{p}<0.05)$.

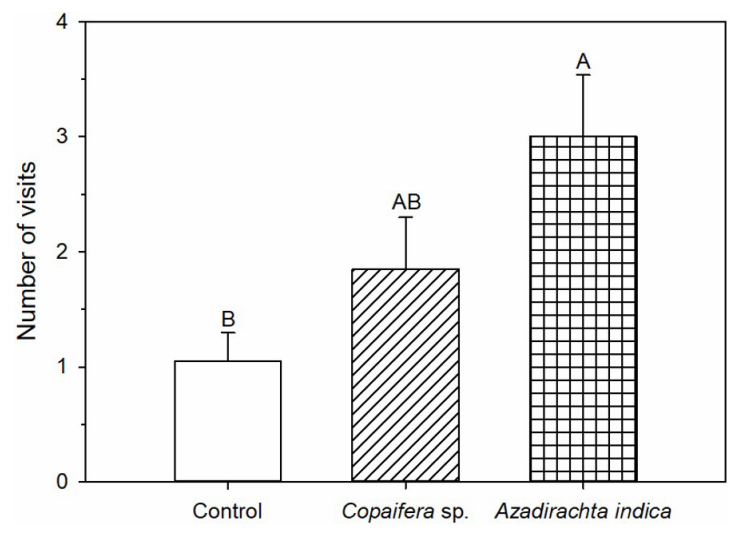

Figure 2. Number of times (mean \pm standard error) that the insect reached the grain mass in the different treatments. The bars followed by the same capital letter do not differ by Tukey's test ( $p<0.05$ ). 
When moving in the direction of the mass, the insects present a different path from that shown around the edge or when they left the group of grains. The movement given by the insects is a meandering path, leaving the border towards the mass of grains. This movement is accompanied

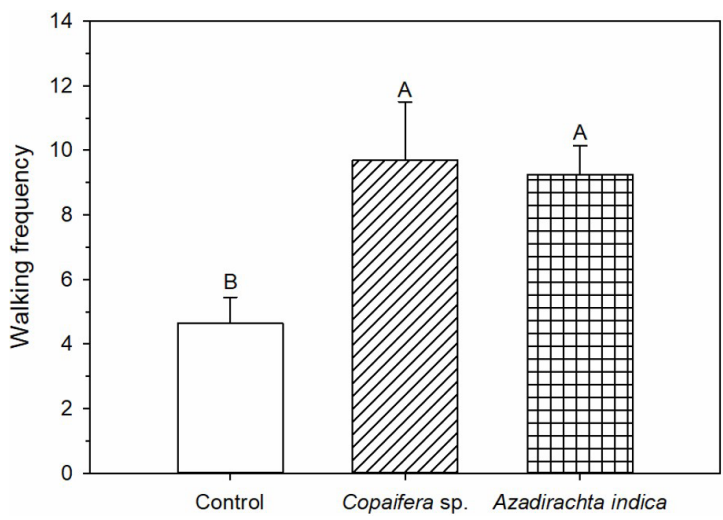

Figure 3. Frequency (mean \pm standard error) of times the insect walked in 30 minutes. The bars followed by the same capital letter do not differ by Tukey's test ( $\mathrm{p}<0.05$ ).

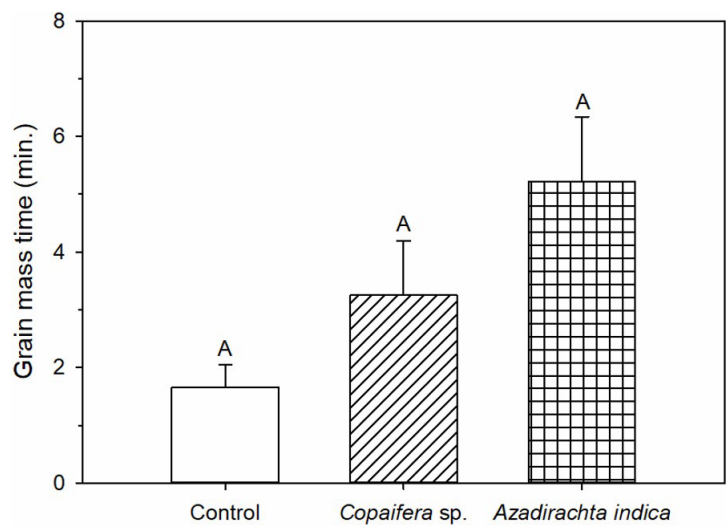

Figure 4. Time (mean \pm standard error) of permanence in the grain mass in minutes in the different treatments. The bars followed by the same capital letter do not differ by Tukey's test ( $\mathrm{p}<0.05$ ).

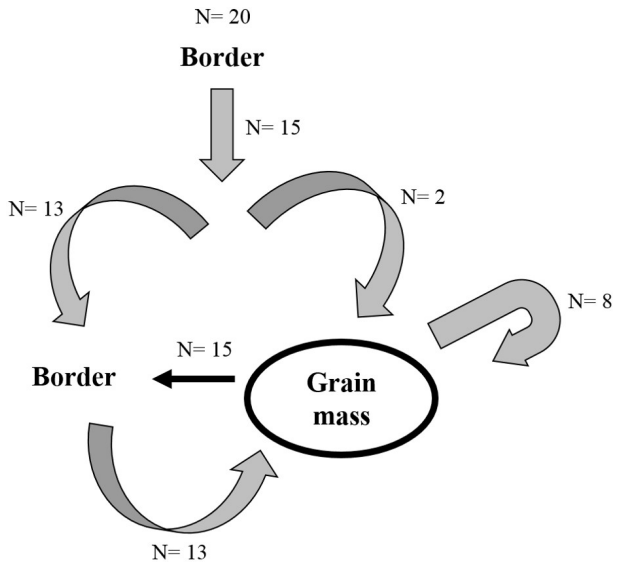

Figure 5. Ethogram of the behavior of Sitophilus zeamais in the presence of the extract of the plant Azadirachta indica. by extended antennas, with the head's movement up and down to the right and left until they reach the grain mass, where they then rise in the mass and remain or leave it. When leaving the mass, the insects can go to the edge, but they can return to the mass in some cases ( 8 times). In the test, only two insects went directly to the edge, and five insects remained walking on the plate without, however, having contact with the grain mass (Figure 5). Insect feeding was not observed in any of the treatments. None of the treatments did the insects remain in the grain mass after the first contact.

\section{Discussion}

The effect of plant compounds affecting insects, especially Coleoptera, has been the objective of some studies (Silva and Martinez, 2004; Hori, 2004; Santana et al., 2021). Neem extract influences insects' behavior and physiology, including the effects on reproduction, reduced feeding, increased mortality, and the occurrence of abnormal and late ecdysis (Barbosa et al., 2002; França et al., 2017). However, there are no reports of the effect of attractiveness on insects. The compound alpha-copaene present in Copaíba oil has already been reported as attractive to Ceratitis capitata (Wiedemann, 1824) (Diptera: Tephritidae) (Jacobson et al., 1987). The attractiveness of plant origin compounds to S. zeamais was shown by Tavares and Vendramim (2005). These authors found the attractiveness of adults of $S$. zeamais in plots of grains treated with a death powder from Santa Maria Herb Chenopodium ambrosioides L. (Chenopodiaceae).

In this work, the neem extract and Copaíba oil had a pleasing effect on S. zeamais. This result was evidenced by the change in the insect's behavior when stimulated by the odor from the treated grain mass, and the time for the first contact in absolute terms was shorter than the control.

The trends in Neem extract and Copaiba oil's attractiveness can be justified by the sum of the odor of corn and volatiles from these tested compounds, forming a more attractive blend than corn alone. In his work, Dickens (2006) found that males and females of Leptinotarsa decemlineata (Say, 1824) (Coleoptera: Chrysomelidae) had a more significant response when the aggregation pheromone produced by the male together with attractive substances from his host plant.

Some insects respond differently to the same substance when varying their dose. By reducing this dosage, a substance with a repellent characteristic can become an attraction for the insect (Hori, 2003, 2004). Oliveira and Vendramim (1999) verified with the dose reduction from 5 to $0.5 \mathrm{~mL}$ of Neem oil / Kg of beans, and there was an increase in the number of Zabrotes subfasciatus (Boh, 1833) (Coleoptera: Bruchidae) attracted. This fact would explain the more significant number of visits and walk, without having the highest permanence in the grain mass due to the concentration (may) not being the ideal one to have a more attractive stimulus to $\mathrm{S}$. zeamais.

The repellent effect of plant chemical compounds may affect the choice of insects to their host plants. But it is also necessary to evaluate the insect's acceptance of food 
containing such chemical compounds. Feeding behavior in insects is dependent on nervous stimuli received by chemical sensors, present in taste receptors in the mouth apparatus and tarsals (Chaudhary et al., 2017). The blocking of insect feeding by azadirachtin occurs through deterrent stimuli in chemoreceptor cells and by inhibiting the cells responsible for perceiving sugars (Jennifer Mordue Luntz et al., 1998). In addition to blocking feeding, azadirachtin ingestion also leads to physiological effects in the insect midgut, which causes a reduction in post-ingestion digestive efficiency (Schmutterer, 1985).

Considering that the latency period is the time the insect spent to reach the grain mass for the first time, the number of visits to the grain mass is the number of times the insect reached, left, and returned to the grain mass, and the walking frequency is the number of times the insect kept walking through the Petri dish without being in contact with the treated grains, during 30 minutes. The fact that the latency period of the plant treatments (Neem extract and Copaiba oil) was shorter compared to the control treatment shows that there was no adverse effect on the attractiveness of food on the insect when treated with these plant extracts. However, the number of visits in the Neem treatment was higher than the other treatments, showing a search for food resources, but not feeding adequately due to the presence of the treatment in the grain mass. This condition causes a more significant agitation in the insects, leading them to walk longer through the Petri dish, searching for a suitable resource source (i.e., grains without the treatments).

The permanence time of the insects in the mass of treated grains, statistically not different from the control, which shows the ability of the insect to locate the food resource even in the presence of the treatments. However, the fact that the insects did not remain in the treated grain masses indicates that the presence of the plant extracts contributes to the inadequacy of the food resource for the insects.

Thus, the latency time contributes to a faster contact of the insects with the chemical compounds present in the plant extracts, leading them to a greater search and displacement by the grain raisin without adequate feeding. Thus, there is a more significant expenditure of energy and no replacement of it; consequently, a lower survival and reproduction rate is expected, contributing to a reduction of the pest population.

We conclude that the sublethal effects of plant compounds with an insecticidal effect can be used in pest control programs, in the sense of monitoring and as an insect repellent. Studies are still needed to clarify these sublethal effects on $S$. zeamais due to a dose-response curve and the implication of these sublethal doses in the insect resistance process.

\section{Acknowledgements}

The authors would like to thank the National Council for Scientific and Technological Development (Conselho Nacional de Desenvolvimento Científico e Tecnológico - CNPq), the Minas Gerais State Research Foundation
(Fundação de Amparo a Pesquisa do Estado de Minas Gerais - FAPEMIG) and the Coordenação de Aperfeiçoamento de Pessoal de Nível Superior - Brasil (CAPES) - Finance Code 001, Universidade Federal de Viçosa and Universidade Federal dos Vales do Jequitinhonha e Mucuri for financially supporting this research.

\section{References}

AJIBOLA TAYLOR, T., 1971. On the flight activity of Sitophilus zeamais Motsch. (Coleoptera, Curculionidae) and some other grain-infesting beetles in the field and a store. Journal of Stored Products Research, vol. 6, no. 4, pp. 295-306. http://dx.doi. org/10.1016/0022-474X(71)90042-7.

ARNASON, J.T., PHILOGÈNE, B.J. and MORAND, P., 1988. Insecticides of plant origin. Ottawa: American Chemical Society. ACS Symposium Series, No. 387, 224 p.

BARBOSA, F.R., YOKOYAMA, M., PEREIRA, P.A.A. and ZIMMERMANN, F.J.P., 2002. Controle do caruncho-do-feijoeiro Zabrotes subfasciatus com óleos vegetais, munha, materiais inertes e malathion. Pesquisa Agropecuária Brasileira, vol. 37, no. 9, pp. 1213-1218. http://dx.doi.org/10.1590/S0100204X2002000900002.

CANSIAN, R.L., STAUDT, A., BERNARDI, J.L., PUTON, B.M.S., OLIVEIRA, D., DE OLIVEIRA, J.V., GOMES, A.C.C., ANDRADE, B.C.O.P., LEAL, I.C.R., SIMAS, N.K., ZENI, J., JUNGUES, A., DALLAGO, R.M., BACKES, G.T. and PAROUL, N., 2023. Toxicity and larvicidal activity on Aedes aegypti of citronella essential oil submitted to enzymatic esterification. Brazilian Journal of Biology = Revista Brasileira de Biologia, vol. 83, pp. e244647. http://dx.doi.org/10.1590/15196984.244647. PMid:34190758.

CHAUDHARY, S., KANWAR, R.K., SEHGAL, A., CAHILL, D.M., BARROW, C.J., SEHGAL, R. and KANWAR, J.R., 2017. Progress on Azadirachta indica based biopesticides in replacing synthetic toxic pesticides. Frontiers of Plant Science, vol. 8, pp. 610-622. http://dx.doi. org/10.3389/fpls.2017.00610. PMid:28533783.

CLOYD, R.A., 2012. Indirect effects of pesticides on natural enemies Pesticides. In: R. P. SOUNDARARAJAN, ed. Advances in chemical and botanical pesticides. London: IntechOpen. http://dx.doi. org/10.5772/48649.

DICKENS, J., 2006. Plant volatiles moderate response to aggregation pheromone in Colorado potato beetle. Journal of Applied Entomology, vol. 130, no. 1, pp. 26-31. http://dx.doi. org/10.1111/j.1439-0418.2005.01014.x.

FORMENTINI, M.A., ALVES, L.F.A. and SCHAPOVALOFF, M.E., 2016. Insecticidal activity of neem oil against Gyropsylla spegazziniana (Hemiptera: Psyllidae) nymphs on Paraguay tea seedlings. Brazilian Journal of Biology = Revista Brasileira de Biologia, vol. 76, no. 4, pp. 951-954. http://dx.doi.org/10.1590/1519-6984.04915. PMid:27143053.

FRANÇA, S.M., BREDA, M.O., BARBOSA, D.R., ARAUJO, A.M. and GUEDES, C.A., 2017. The sublethal effects of insecticides in insects. In: V.D.C. SHIELDS, ed. Biological control of pest and vector insects. London: IntechOpen. http://dx.doi.org/10.5772/66461.

GOMES, J.M., 1992. SAEG: sistema de análises estatísticas e genéticas. Versão 5.0. Viçosa: UFV, 100 p.

GUEDES, R., 1991. Resistência a inseticidas: desafio para o controle de pragas de grãos armazenados. Seiva, vol. 50, pp. 24-29.

GUEDES, R.N.C., LIMA, J.G., SANTOS, J.P. and CRUZ, C.D., 1995. Resistance to DDT and pyrethroids in Brazilian populations of Sitophilus zeamais Motsch.(Coleoptera: curculionidae). Journal 
of Stored Products Research, vol. 31, no. 2, pp. 145-150. http:// dx.doi.org/10.1016/0022-474X(94)00043-S.

GULLAN, P. and CRANSTON, P., 2017. Insetos: fundamentos da entomologia. 5. ed. Rio de Janeiro: Guanabara Koogan, 436 p.

HORI, M., 2003. Repellency of essential oils against the cigarette beetle, Lasioderma serricorne (Fabricius)(Coleoptera: anobiidae). Applied Entomology and Zoology, vol. 38, no. 4, pp. 467-473. http://dx.doi.org/10.1303/aez.2003.467.

HORI, M., 2004. Repellency of hinokitiol against the cigarette beetle, Lasioderma serricorne (Fabricius) (Coleoptera: anobiidae). Applied Entomology and Zoology, vol. 39, no. 3, pp. 521-526. http://dx.doi.org/10.1303/aez.2004.521.

ILAHI, I., YOUSAFZAI, A.M., ATTAULLAH, M., HAQ T.U., RAHIM, A., KHAN, W., KHAN, A.A., ULLAH, S., JAN, T., KHAN, M.M., RAHIM, G. and ZAMAN, N., 2021. Mosquitocidal activities of Chenopodium botrys whole plant n-hexane extract against Culex quinquefasciatus. Brazilian Journal of Biology = Revista Brasileira de Biologia, vol. 83, pp. e240842. http://dx.doi.org/10.1590/15196984.240842. PMid:34550279.

JACOBSON, M., UEBEL, E.C., LUSBY, W.R. and WATERS, R.M., 1987. Optical isomers of. alpha.-copaene derived from several plant sources. Journal of Agricultural and Food Chemistry, vol. 35, no. 5, pp. 798-800. http://dx.doi.org/10.1021/jf00077a038.

JENNIFER MORDUE LUNTZ, A., SIMMONDS, M.S.J., LEY, S.V., BLANEY, W.M., MORDUE, W., NASIRUDDIN, M. and NISBET, A.J., 1998. Actions of azadirachtin, a plant allelochemical, against insects. Pesticide Science, vol. 54, no. 3, pp. 277-284. http:// dx.doi.org/10.1002/(SICI)1096-9063(1998110)54:3<277::AIDPS801>3.0.CO;2-I.

LEE, C-Y., 2000. Sublethal effects of insecticides on longevity, fecundity and behavior of insect pests: a review. Journal of Bioscience, vol. 11, no. 1-2, pp. 107-112.

LIKHAYO, P.W. and HODGES, R.J., 2000. Field monitoring Sitophilus zeamais and Sitophilus oryzae (Coleoptera: Curculionidae) using refuge and flight traps baited with synthetic pheromone and cracked wheat. Journal of Stored Products Research, vol. 36, no. 4 pp. 341-353. http://dx.doi.org/10.1016/S0022-474X(99)00052-1. PMid: 10880812

MENDONÇA, F.A., DA SILVA, K.F., DOS SANTOS, K.K., RIBEIRO JÚNIOR, K.A. and SANT'ANA, A.E., 2005. Activities of some Brazilian plants against larvae of the mosquito Aedes aegypti. Fitoterapia, vol. 76, no. 7-8, pp. 629-636. http://dx.doi.org/10.1016/j. fitote.2005.06.013. PMid:16253435.

MITUIASSU, L.M.P., SERDEIRO, M.T., VIEIRA, R.R.B.T., OLIVEIRA, L.S. and MALECK, M.2022. Momordica charantia L. extracts against Aedes aegypti larvae. Brazilian Journal of Biology = Revista Brasileira de Biologia, vol. 82, pp. e236498. http://dx.doi. org/10.1590/1519-6984.236498. PMid:33787746.

MOREIRA, M.D., PICANÇO, M.C., BARBOSA, L.C.A., GUEDES, R.N.C., CAMPOS, M.R., SILVA, G.A. and MARTINS, J.C., 2007. Plant compounds insecticide activity against Coleoptera pests of stored products. Pesquisa Agropecuária Brasileira, vol. 42, no. 7, pp. 909-915. http://dx.doi.org/10.1590/S0100-204X2007000700001.
NWACHUKWU, I.D. and ASAWALAM, E.F., 2014. Evaluation of freshly prepared juice from garlic (Allium sativum L.) as a biopesticide against the maize weevil, Sitophilus zeamais (Motsch.) (Coleoptera: curculionidae).Journal of Plant Protection Research, vol.54, no. 2, pp. 132-138. http://dx.doi.org/10.2478/ jppr-2014-0021.

OLIVEIRA, J.V. and VENDRAMIM, J.D., 1999. Repelência de óleos essenciais e pós vegetais sobre adultos de Zabrotes subfasciatus (Boh.) (Coleoptera: Bruchidae) em sementes de feijoeiro. Anais da Sociedade Entomológica do Brasil, vol. 28, no. 3, pp. 549-555. http://dx.doi.org/10.1590/S0301-80591999000300026.

PERERA, A., KARUNARATNE, M. and CHINTHAKA, S., 2017. Biological activity and secondary metabolite profile of Ruta graveolens leaves against maize weevil infestations. Journal of Entomology and Zoology Studies, vol. 5, no. 2, pp. 233-241.

RODRÍGUEZ, C., 1999. Recetas de Nim Azadirachta indica (Meliaceae) contra plagas. In: Memorias VSimposio nacional sobre sustancias vegetales y minerales en el combate de plagas, 1999, Aguas Calientes, México. Aguas Calientes, México: Sociedad Mexicana de Agricultura Sostenible A. C., pp. 39-59.

SÂMIA, R.R., DE OLIVEIRA, R., MOSCARDINI, V. and CARVALHO, G., 2016. Effects of aqueous extracts of Copaifera langsdorffii (Fabaceae) on the growth and reproduction of Spodoptera frugiperda (JE Smith) (Lepidoptera: noctuidae). Neotropical Entomology, vol. 45, no. 5, pp.580-587. http://dx.doi.org/10.1007/ s13744-016-0398-6. PMid:27143141.

SANTANA, C.B., SOUZA, J.G.L., TOLEDO, A.G., ALVES, L.F.A., ALVES, D.S., CORRÊA, J.M. and PINTO, F.G.S., 2021. Antimicrobial and insecticidal effects of essential oil and plant extracts of Myrcia oblongata DC in pathogenic bacteria and Alphitobius diaperinus. Brazilian Journal of Biology = Revista Brasileira de Biologia, vol. 82, pp. e233425. http://dx.doi.org/10.1590/1519-6984.233425. PMid:34105655.

SCHMUTTERER, H., 1985. Which insect pests can be controlled by the application of neem seed kernel extracts under field conditions?. Zeitschrift für Angewandte Entomologie, vol. 100, no. 1-5, pp. 468-475. http://dx.doi.org/10.1111/j.1439-0418.1985. tb02808.x.

SILVA, F.A. and MARTINEZ, S.S., 2004. Effect of neem seed oil aqueous solutions on survival and development of the predator Cycloneda sanguinea (L.) (Coleoptera: coccinellidae). Neotropical Entomology, vol. 33, no. 6, pp. 751-757. http://dx.doi.org/10.1590/ S1519-566X2004000600013.

TAVARES, M.A. and VENDRAMIM, J.D., 2005. Bioatividade da erva-de-santa-maria, Chenopodium ambrosioides L., sobre Sitophilus zeamais Mots. (Coleoptera: curculionidae). Neotropical Entomology, vol. 34, no. 2, pp.319-323. http://dx.doi.org/10.1590/ S1519-566X2005000200021.

TOFEL, K.H., KOSMA, P., STÄHLER, M., ADLER, C. and NUKENINE, E.N., 2017. Insecticidal products from Azadirachta indica and Plectranthus glandulosus growing in Cameroon for the protection of stored cowpea and maize against their major insect pests. Industrial Crops and Products, vol. 110, pp. 58-64. http://dx.doi. org/10.1016/j.indcrop.2017.09.051. 